\title{
INTELLECTUAL CAPITAL AS A FINANCIAL PERFORMANCE MEASUREMENT IN PUBLIC SECTOR
}

\author{
${ }^{1}$ Alimuddin, ${ }^{2}$ Eni Novitasari, ${ }^{3}$ Hisyam Ichsan, ${ }^{4}$ Andi lqra Pradipta \\ 1,2,3,4Hasanuddin University, Jl. Perintis Kemerdekaan Km. 10, Tamalanrea Indah, Makassar, \\ South Sulawesi, Indonesia, eninovitasariimron061192@gmail.com
}

\begin{abstract}
The purpose of this study is to know the correlation between intellectual capital and financial performance with intellectual capital disclosure as moderation variable. The intellectual capital variable as the dependent variable is measured by using the VAIC indicator (Value Added Intellectual Capital) while for the independent variable is the financial performance measured by expense efficiency ratio, revenue variance ratio, revenue growth ratio, $P A D$ growth ratio, capital expenditure ratio, and financial dependency ratio. And for the moderation variable is intellectual capital disclosures measured by ICDS indicator (Intellectual Capital Disclosures Score). And the object of study is Financial Report of Local Government in South Sulawesi Province. This study is using quantitative research approach by using a secondary data source. Data collection technique used is purposive sampling method. Analysis of the data in this study using multiple linear regression (multiple regression) to analyze the impact of the independent variable on the dependent variable and moderating variable with statistical software. From this study, it can be concluded that there is no significant correlation between intellectual capital and the financial performance of government institutions and there is a significant correlation between intellectual capital disclosure to the financial performance of government institutions and intellectual capital disclosures can moderate the relationship between intellectual capital and financial performance of government institutions.
\end{abstract}

Keywords: Intellectual Capital, Intellectual Capital Disclosures, Financial Performance 


\section{Introduction}

The rapid development of technology and information makes it easier for people to obtain information. The development of this information also led to higher levels of alienation that occurred among organizations. Experts who study on the importance of Intellectual Capital in various fields of accounting, business, management, information technology, and sociology as submitted by Ulum (2009). The current measurement of performance can no longer be done by only considering aspects only in physical financially form but also have considered intangible assets such as intellectual capital, where intellectual capital is one of the measuring instruments used to view the performance of the organization, especially the private sector.

The application of intellectual capital is a form of the implications of a strong organizational culture. A strong organizational culture that expected to always sustain and create the core values of their organization both on human aspects, structure, and relationships. In the field of intellectual capital, accounting is very important to be managed well for the development of intellectual capital can fix the flaws in the quality of their financial statements.

In Indonesia, research on the linkage between intellectual capital disclosure and organizational financial performance is not only done in the banking sector which is highly conditional on innovation but has also penetrated to other private sector organizations. This is evidenced by the research conducted by Dewi et al., which relates to factors affecting intellectual capital disclosure in companies listed on the Indonesian Stock Exchange found that firm size, company age, and status listing have significant influence on intellectual capital disclosure, While the type of industry and managerial ownership have no significant effect. On the other hand, research on intellectual capital has also been done by Kristanto (2010) conducted in public sector which found that there is a significant relationship between Intellectual Capital Variation and Civil Servant's Value Perception. Other studies related to intellectual capital in the public sector found that VAIC (value added intellectual capital) did not affect the financial performance of the company, where Human Capital Efficiency did not affect the company's financial performance, while Structural capital efficiency And Capital Employed efficiency had a positive effect on the company's financial performance and the VAIC last year did not affect the company's performance this year.

Disclosure of intellectual capital is considered to be helpful to improve the relevance of the annual report. The value of an organization is not only determined by physical assets but also based on the quality of the company's resources such as knowledge, expertise, innovation possessed by employees (Intellectual Capital) requires the company to provide a larger portion in the use of intangible assets. Disclosure of Intellectual Capital is often used as a measure of organization. One reason is that in determining the performance of organizational, intellectual capital is not only focusing on financial measures but considering the non-financial measurements, such as human capital, structural capital and external capital. Where human capital in this case related to the knowledge, skill, experience, intuition, and attitude of the employees. And structural capital consists of various patents, concepts, models, and computer and administrative systems created by employees. While external capital is a significant customer capital related to the organization's relationship with its customers. 
Several studies have been conducted to examine the relationship between intellectual capitals with organizational performance. One study on the linkage made by Chen et al., (2005) who found a significant relationship between the intellectual capital to the company's financial performance with samples of the public company in Taiwan Stock Exchange. Research is also conducted Hashim et al., (2015) who found that intellectual capital has a significant influence on organizational performance in Malaysia. Other research conducted by Gogan et al., (2016) found a significant relationship between intellectual capital and organizational performance.

Before looking the effect of intellectual capital on the organizational performance. It is important to classify whether the effect caused by the value of intellectual capital, or because of the disclosure of intellectual capital. To measure the value of intellectual capital can be used the method of Value Added Intellectual Capital (VAIC). And for intellectual capital disclosure, can use Intellectual Capital Disclosure Score (ICDs). In Indonesia, research development about intellectual capital just focuses on the private sector, even though the intellectual capital of the organization is not only the private sector but also the public sector.

From the phenomena, we can see that intellectual capital study just focus in private sector. So for this study, we will do the same research but different object. For this study, we will use the Regional Government in the Province of South Sulawesi as an object. Then this study classifies the value of Intellectual Capital and intellectual capital disclosure which in turn is associated with an influence on the financial performance of the public sector.

The purpose of this study was to determine the effect of intellectual capital on the financial performance of government agencies, and the effect of Intellectual capital disclosure on the financial performance of government agencies as well as to determine the relationship between intellectual capital and intellectual capital disclosures on financial performance in government agencies.

\section{Literature Review}

\subsection{Stakeholder Theory}

This study use stakeholder theory as a theoretical basis. Stakeholder theory is a theory developed by Donalson and Preston in 1995. In their study, Donalson and Preston (1995) state that the stakeholder theory explains that the company or organization has the stakeholders, but has no direct influence in the managerial organization.

Freeman (1983) in developing the stakeholder theory introduced the concept of stakeholder in two models, (a) the policy and planning models and (b) a model of corporate social responsibility of the management stakeholders. In the first model, that the stakeholder concept, the focus is to develop and evaluate the company's strategic decision approval with groups whose support is necessary for the company's sustainability. It can be said that, in this model, stakeholder theory focuses on the ways that can be used by companies to manage the company's relationship with its stakeholders. While in the second model, corporate planning and analysis are expanded by incorporating possible external influences for the company. These opposing groups include regulatory bodies (government) with special interests that have concerns about social issues. 
If this theory is associated with the type of disclosures made by the company, the company will perform in accordance with the disclosure that does the most influential stakeholder interest on the continuity of the company's life. One type of disclosure that is increasingly carried out by organizations today is the intellectual capital disclosure of the organization. Intellectual capital disclosure at this time is not only done by the organization in private sector, but also in the public sector. Lately, government agencies have done disclosure in the form of intellectual capital in their financial statements to provide accountability for a more transparent and accountable to the public. And with increasingly transparent financial information government agencies are expected later on the public can obtain information about the performance of government agencies, especially those related to financial performance.

Davey and Eggleton (2011) state that the stakeholder theory explains the organization's relationship with the various stakeholder groups in the community. In this theory, organizations are part of a wider social system. From the perspective of stakeholder theory, organizations should undertake responsibility not only to shareholders but also to other stakeholders (stakeholders). In their study, they stated that the stakeholder theory is an extension of the agency theory which focuses on the relationship between the principal - agent. However, the difference of both theories is that the stakeholder theory does not utilize the concept of information asymmetry. Therefore, in explaining the voluntary disclosure practice intellectual capital, both theories need to be integrated. So as a consequence, we can conclude that the voluntary disclosure of intellectual capital can reduce the asymmetry of information between organizations and various stakeholders, and improve relations between them.

\subsection{Resource Based View Theory}

As mentioned above, in addition to using stakeholder theory in this study using resource-based view theory (RBV) as a theoretical basis. Resource-based view theory (RBV) is one dominant contemporary approach used to analyze the sustainable competitive advantage of an organization. Mulyono (2013) states that the resource-based theory is trying to explain why in the same industry there are companies that succeed while many there are not successful. The main premise of articles used in the resourcebased theory is that companies compete on the basis of their resources and capabilities (Peteraf and Bergen, 2003).

Peteraf and Barney (2003) stated in their paper that resource-based views emphasize that corporate resources are a fundamental factor determining the benefits and competitive performance of an organization. This view adopts two assumptions to analyze the source of competitive advantage. First, this model assumes that companies in an industry (or strategic) may be heterogeneous with respect to the set of resources they control. Second, it is assumed that resource heterogeneity can persist over time because the resources used to implement corporate strategy are not perfect across the enterprise (some resources cannot be traded in the market and are difficult to accumulate and replicate).

Chun (2016) said that the main thrust resource-based view company are heterogeneous and this heterogeneity includes the development of skills 
and the ability to access and control resources. In writing the resource-based view has direct implications on the level of aspiration of the company, such company must make decisions about what resources should be spent and in what ways depending on what is considered the most important objectives of the company.

Broadly speaking, the resource-based view of this theory explains that a company or organization cannot hope to buy or take a sustainable competitive advantage of an organization owned by others, because of these advantages is a scarce resource, it is difficult to imitate, and irreplaceable. In a resource-based view, one of the advantages of the organization relating to sustainable competitive advantage, one of the determining factors derived from internal resources are one of the components of the internal resource is human capital.

Sutrisno and Lina (2014) stated that basically human capital is the soul of the company and can be divided into three main components, such as competence, attitude, and intelligence. While Rehman et al. (2011) define human capital as the skills and creativity of employees who can be encouraged by investing more in their training programs. It can be concluded that human capital is the experience and expertise of employees who improve organizational efficiency.

\section{Hypothesis}

Hasim et al. (2015) stated that intellectual capital (IC), also known as the new intangible assets and the most common definition of intellectual capital is the knowledge that is valuable to an organization. But unfortunately, one of the challenges in managing intellectual capital is when managers do not know that their company has a valuable resource, which can provide the success of the new strategy. It has been recognized by many researchers that intellectual capital is the most important strategic asset in evaluating the performance of an organization in developing countries and underdeveloped countries.

The few studies that have been done with regards to intellectual capital and financial performance is shown in the table below. 
Table 1 Studies on Intellectual Capital and Financial Performance

\begin{tabular}{|c|c|c|c|}
\hline NO & AUTHOR & TITLE & RESULT \\
\hline 1 & Cleary (2015) & $\begin{array}{l}\text { An Empirical } \\
\text { Investigation of The } \\
\text { Impact of } \\
\text { Management } \\
\text { Accounting on } \\
\text { Structural Capital } \\
\text { and Business } \\
\text { Performance }\end{array}$ & $\begin{array}{l}\text { - There is no relationship } \\
\text { between management } \\
\text { accounting and business } \\
\text { performance } \\
\text { - intellectual capital } \\
\text { significantly influence } \\
\text { business performance }\end{array}$ \\
\hline 2 & $\begin{array}{l}\text { Fathi, et al. } \\
(2013)\end{array}$ & $\begin{array}{l}\text { Impact of Intellectual } \\
\text { Capital on Financial } \\
\text { Performance }\end{array}$ & $\begin{array}{l}\text { - There is a positive } \\
\text { relationship between } \\
\text { intellectual capital } \\
\text { performances in the } \\
\text { telecommunications sector } \\
\text { organizations in Pakistan. }\end{array}$ \\
\hline 3 & $\begin{array}{l}\text { Shehzad et } \\
\text { al. (2014) }\end{array}$ & $\begin{array}{l}\text { The Impact of } \\
\text { Intellectual Capital on } \\
\text { the Performance of } \\
\text { Universities }\end{array}$ & $\begin{array}{l}\text { - There is a significant } \\
\text { correlation with the } \\
\text { performance but among the } \\
\text { three components, the } \\
\text { relationship of human capital } \\
\text { is more prominent than the } \\
\text { other two components of } \\
\text { intellectual capital. }\end{array}$ \\
\hline
\end{tabular}

Based on the relationship between the concept and previous research, the conceptual framework used in this study, as follows:

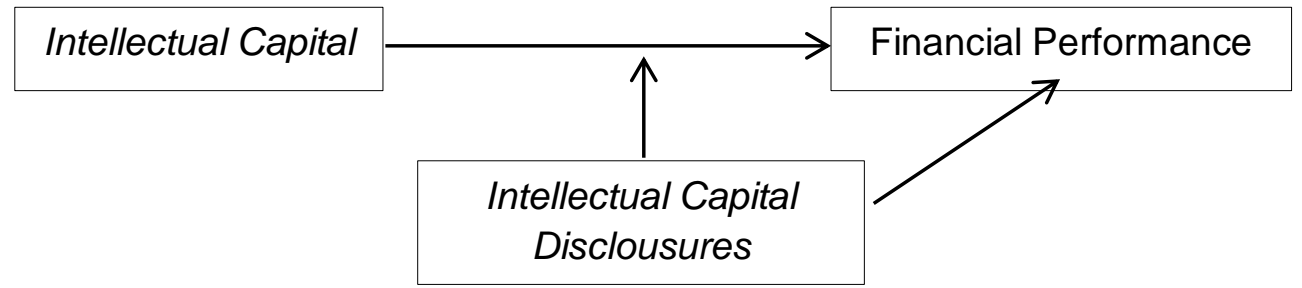

Figure 1. Conceptual Framework

Hashim et al. (2015) stated that intellectual capital is a new form of intangible assets and is widely used to define the intellectual capital is the knowledge of value to an organization. Dinaki (2014) conducted a study that deals with the relationship between intellectual capital and performance of Bank Saderat in Tehran. He found that there is significant influence between intellectual capitals with the performance. From these dimensions, customer capital has the highest influence on the performance and structural capital was ranked second, followed by human capital in third place and has the lowest influence on performance.

Cleary (2015) has also conducted research related to the impact of management accounting in structural capital and business performance that obtained the result that after testing the three framework models related to intellectual capital mainly related to structural capital and financial performance 
there is no relationship between accounting management with business performance, but on the other hand the result obtained that intellectual capital significantly influence business performance. And some previous studies that have been described above, we can lower the hypothesis as follows:

$\mathrm{H}_{1}$ : There is a significant relationship between intellectual capital and financial performance of government agencies.

Ferreira et al. (2012) found that the information disclosed by the company often associated with intellectual capital is information about external capital. Thus, hypotheses can be derived as follows:

$\mathrm{H}_{2}$ : Intellectual capital disclosures affect the financial performance of government agencies.

And from the few studies that have been mentioned above, we can see that there is a relationship between intellectual capital and financial performance as well as intellectual capital disclosures and financial performance. Thus, the following hypothesis is derived:

$\mathrm{H}_{3}$ : Intellectual capital disclosures may moderate the relationship between intellectual capital and financial performance.

\section{Research Methodology}

This research uses quantitative research method by using the indirect method. The sample used in the study is the Local Government Financial Statement of South Sulawesi which amounted to 48 financial reports of the district/city government. Sample selection method used is non-probability sample selection based on criteria (purposive sampling).

The type of data used is documentary data in the form of financial statements indicating that the type of data used in the form of numbers - figures presented in the financial statements of Local Government Regional. And the data source used in this research is secondary data that is data source obtained indirectly from the original source or through an intermediary.

4.1. Intellectual Capital

To measure the intellectual capital variables is to use value-added obtained from the sum of physical capital (VACE), human capital (VAHU), and structural capital (STVA). Where value added is then symbolized VAIC, as follows:

$$
\begin{array}{lr}
\text { Human capital efficiency }(\mathrm{HCE}) & =\frac{\text { value added }(V A)}{\text { human capital }(H C)} \\
\text { Structural capital efficiency }(\mathrm{SCE}) & =\frac{\text { structural capital }(S C)}{\text { value added }(\mathrm{VA})} \\
\text { Capital employed efficiency }(\mathrm{CEE}) & =\frac{\text { structural capital }(S C)}{\text { capital employed }(C E)}
\end{array}
$$

Thus, the formulation used to calculate Value added intellectual coefficient developed Berzkalnea and Zelgalve (2014), as follows:

Value-added intellectual coefficient $($ VAICTM $)=$ HCE + SCE + CEE

\subsection{Financial Performance}

To assess the financial performance of regions in this study using the ratio scale. The formulation that can be used to determine the percentage of financial performance from Natalia and Astuti (2015), as follows: 
4.2.1. Efficiency expenditure analysis

Efficiency expenditure ratio $=\frac{\text { Expenditure realization }}{\text { Expenditure budgeting }} \times 100 \%$

4.2.2. Revenue variance analysis

Revenue variance ratio $=\frac{\text { Revenue Realization }}{\text { Revenue budgeting }} \times 100 \%$

4.2.3. Revenue growth analysis

Revenue growth ratio $=\frac{\operatorname{Revenue}(t)-\text { Revenue }(t-1)}{\operatorname{Revenue}(t)} \times 100 \%$

4.2.4. $P A D$ growth analysis

PAD growth ratio $=\frac{P A D(t)-P A D(t-1)}{P A D(t-1)} \times 100 \%$

4.2.5. $P A D$ effectiveness analysis

$$
\text { PAD effectiveness ratio }=\frac{P A D \text { Realization }}{P A D \text { Target }} \times 100 \%
$$

4.2.6. Expenditure harmonization analysis

Expenditure harmonization ratio $=\frac{\text { operating expenditure realization }}{\text { Total expenditure }} \mathrm{x}$ $100 \%$

4.2.7. Capital expenditure analysis

$$
\text { Capital expenditure ratio }=\frac{\text { Capital expenditure realization }}{\text { Total expenditure }} \times 100 \%
$$

4.2.8. Financial dependency analysis

Financial dependency ratio $=\frac{\text { Transfer revenue }}{\text { Total } P A D} \times 100 \%$

\subsection{Intellectual Capital Disclosure}

To assess disclosures intellectual capital will be used in the form of intellectual capital indicators disclosures score (ICDS) by using the scale ratio by using a model that has been developed by Guthrie and Petty (2000). With the formulation of the intellectual capital calculation disclosures score, as:

$$
\text { ICDScore }=\frac{\sum_{i=1}^{m} \text { HCScore }+ \text { SCScore }+ \text { CCScore }}{m}
$$

\section{Results}

Results of tabulation data used by SPSS 22shown in Table 5.1 that the Rvalue is 0.231 indicates that the influence of the independent variable is intellectual capital and the dependent variable, the financial performance of government agencies amounted 23.1 percent which indicates that the effect of the dependent variable to independent variables is weak. As for the value of $R^{2}(R$ square) is 0053, which means that contribution of the intellectual capital to financial performance is 5.3 percent. And the rest is 94.7 percent influenced by other factors.

From table 5.2. (Appendix), we can see that the $t$ value for the variable $X_{1}$ is equal to 1,608 with t table amounted to 0.67986 and a significance level 0.115 . The significant value $0.115>0.05$ and $t$ value $>t$ table means that the variable intellectual capital has no influence on the performance of the organization. This suggests that $\mathrm{H}_{1}$ "intellectual capital significantly influence the financial performance of government agencies" rejected. Which means that there is no influence of the intellectual capital value government agencies to the financial 
performance of government agencies. The results of this study, same with the research that has been done by Schaper et al. (2017) who found that there is no significant influence of intellectual capital on organizational performance. Where in his research, Schaper et al. (2017) identify a general trend for companies, especially companies in Denmark to keep its intellectual capital information, so they tend to not disclose information relevant to the value externally. Similar findings were also found by Dumay (2016) that companies tend to report their organization's intellectual capital in particular and sometimes not included in the annual financial statements. And in another study conducted by Singh and Kansal (2011) who found that there is a negative relationship, weak and not significant due to the disclosure of the intellectual capital is still a voluntary disclosure.

The cause of the low value of intellectual capital when another improved financial performance is not influential disclosures intellectual capital on organizational performance is due to the performance of government agencies today are still using the traditional organizational performance measurement that only pays attention to the physical capital efficiency of the intellectual capital efficiency. Besides the disclosure of the intellectual capital in the sector included in the voluntary disclosure.

Table 5.3 shows that the R-value of 0392 indicates that the influence of the independent variable is intellectual capital to the dependent variable, the financial performance of government agencies amounted to 39.2 percent which indicates that the effect of the dependent variable is intellectual capital and intellectual capital disclosures to independent variables, financial performance is weak. As for the value of $R^{2}$ (R square) of 0154 , which means that the variable contribution of intellectual capital and intellectual capital disclosures to the financial performance was 15.4 percent. And the rest of 84.6 percent influenced by other factors.

From table 5.4. we can see that the $t$ value for the variable $\mathrm{X}_{2}$ is-2314 with $\mathrm{t}$ table amounted to 0.67986 and a significance level of 0.025 . The significant value of $0.025>0.05$ and $t$ value <t table means that the variable intellectual capital disclosures significant effect on the financial performance of government agencies. This suggests that $\mathrm{H}_{2}$ "intellectual capital disclosures significant effect on the financial performance of government agencies" acceptable. This suggests that the greater the value of intellectual capital disclosures to the financial performance of government agencies are also getting better.

Table 5.5 shows that the R-value of 0.440 indicates that the influence of the independent variable is intellectual capital that is moderated by the intellectual capital of the dependent variable disclosures financial performance of government agencies amounted to 44 percent which shows that the influence of the independent variable to dependent variable is weak. As for the value of $R^{2}$ ( $R$ square) of 0163 , which means that the variable contribution of intellectual capital that is moderated by disclosures intellectual capital to financial performance was 16.3 percent. And the rest of 83.7 percent influenced by other factors.

From Table 5.6.above, we can see that the $t$ value for the variable intellectual capital moderated by intellectual capital disclosures amounted to -2 432 with t table amounted to 0.67986 and a significance level of 0.019 . The significant value of $0.019>0.05$ and $t<t$ table means that the variable intellectual capital disclosures moderated by intellectual capital disclosures effect on financial performance. This shows that $\mathrm{H}_{3}$ "intellectual capital moderated by intellectual capital disclosures has a significant effect on the financial performance of government agencies" acceptable. 
From three tests above, we can see that overall there is a significant relationship between intellectual capitals moderated by intellectual capital disclosures on the financial performance of government agencies in the province of South Sulawesi. And if we look at the value $R$ of the three tests above, we can conclude that the intellectual capital disclosures may increase the relationship between intellectual capital and financial performance of government agencies in the province of South Sulawesi.

\section{Conclusion}

This study found that there was not a significant relationship between intellectual capital and financial performance of government agencies and the relationship between intellectual capital disclosures has a significant effect on the financial performance of government agencies and intellectual capital disclosures may moderate the relationship between intellectual capital and financial performance of the organization. The result of this study means that intellectual capital disclosure can increase the relationship between intellectual capital and financial performance in government agencies. The absence of the effect of intellectual capital on the financial performance of government agencies in this study due to the intellectual capital are disclosed in the financial statements of government agencies is still the disclosure is voluntary and there is also a tendency for government agencies only disclosure-related items that are included in the disclosure mandatory in their financial statements. Thus, the results obtained do not have a significant impact on the financial performance of the organization. Disclosure of intellectual capital is mostly done by government agencies are disclosures relating to human capital. Items are included in human capital are the items are included in spending on goods and services, which includes training and scholarships and for employee expenditure therein are fee and employee incentives.

For internal capital disclosed are a permanent and non-permanent investment. Especially that relate to the government's investment by local companies as well as intangible assets, information system (software and website). Items are disclosed in the financial statements of government agencies relating to intellectual capital have a tendency that items must be disclosed because it has a high material value. And in a study conducted by Husin and Olesen (2012) states that the measurement of intellectual capital disclosures only describes the quantity of intellectual capital disclosures rather than on the quality of government institutions disclosure of intellectual capital.

Implications of the study are expected by the study, the local government should carefully consider the owned intellectual capital, so as to put the right people in accordance with their expertise.

For further research is expected researchers to take into consideration the design of research on the intellectual capital will be testing whether directly or separated - separated, which examines the effect of human capital, structural capital and external capital to financial performance. And also to consider the material and non-material value of Intellectual Capital. Due to the intellectual capital not only has a material value but also has a non-material value.

Limitations of this study are in this study, we use the value-added intellectual capital as a measure of intellectual capital, so our test is the overall test of the value of intellectual capital which we may not be able to view the categories of intellectual capital that will influence the performance of the organization. Another 
limitation of this study is in assessing financial performance in this study, we use only one type of performance measurement only.

\section{REFERENCE}

Berzkalnea, Irina dan Elvira Zelgalve. (2014). Intellectual Capital and Company Value. Procedia - Social and Behavioral Sciences. pp. 887-896.

Chen, M.C., S.J. Cheng, dan Y. Hwang. (2005). An Empirical Investigation of The Relationship Between Intellectual Capital and Firms' Market Value and Financial Performance. Journal of Intellectual Capital, 6(2), 159-176.

Chun, Douglas CMK. 2016. Exploring Connections: Aspiration Levels, Culture and The Resource-Based View. Journal of Strategy and Management, 9(2).

Cleary, Peter. (2015). An Empirical Investigation of The Impact of Management Accounting on Structural Capital and Business Performance. Journal of Intellectual Capital, 16 (3), 566 - 586.

Davey, Howard, Yi An, and lan R.C. Eggleton. (2011). Towards a Comprehensive Theoretical Framework for Voluntary IC Disclosure. Journal of Intellectual Capital, 12(4), 571-585.

Dewi, Kencana, Mukhtaruddin Young, and Ria Sundari. (2014). Firm Characteristic and Intellectual Capital Disclosure on Service Companies Listed in Indonesia Stock Exchange period 2008-2012. Journal of Accounting, Auditing, Economics and Financial, 2(2), 22-35.

Dinaki, AbdollahAran. (2014). The study of the relationship between intellectual capital and performance in Saderat bank of Tehran. International Academic Journal of Business Management, 3(9), 9 - 17.

Donaldson, Thomas, and Lee E. Preston. (1995). The Stakeholder Theory of the Corporation: Concepts, Evidence, and Implications. The Academy of Management Review, 20(1), 65-91.

Dumay, J., Bernardi, C., Guthrie, J. and Demartini, P. (2016). Integrated Reporting: A Structured Literature Review. Accounting Forum, 40(3),166-185.

FathiSaeed, ShekoofehFarahmand, and MahnazKhorasani. (2013). Impact of Intellectual Capital on Financial Performance. International Journal of Academic Research in Economics and Management Sciences, 2(1), 6-17. 
Ferreira, Ana Lúcia, Manuel CasteloBrancodan José António Moreira. (2012). Factors Influencing Intellectual Capital Disclosure by Portuguese Companies. International Journal of Accounting and Financial Reporting, 2(2), 278-298.

Guthrie, J. dan Petty, R. (2000). Intellectual Capital: Australian Annual Reporting Practices. Journal of Intellectual Capital, 1(3), 241-251.

Gogan, Luminita Maria, AlinArtene, loanaSarca, and AncaDraghici. (2016). The Impact of Intellectual Capital on Organizational Performance. Procedia - Social and Behavioral Sciences, pp. $194-202$.

Hashim, Maryam Jameelah, Idris Osman, and Syed Musa Alhabshi. (2015). Effect of Intellectual Capital on Organizational Performance. Procedia - Social and Behavioral Sciences, pp. $207-214$.

Husin, Norhayati Mat dan Keith Hooper, and Karin Olesen. (2012). Analysis of Intellectual Capital Disclosure - An Illustrative Example. Journal of Intellectual Capital, 13(2), 196-220.

Kristanto, Bayu Septian. (2010). Intellectual Capital Variation dan Value Perception (Studi Pada Sektor Pemerintahan). Jurnal Akuntansi, 10(3), 293-304.

Mulyono, Fransisca. (2013). Sumber Daya Perusahaan dalamTeori Resource-based View. JurnalAdministrasiBisnis, 9(1), 59-78.

Natalia, Listiyani dan Tutut Dewi Astuti. (2015). Analisis Laporan Keuangan dalam Mengukur Kinerja Keuangan Pada Pemerintah Kabuaten Sleman. Jurnal Sosio-Humaniora, 6(1), 55-72.

Peteraf, Margaret, and Bergen, Mark. (2003). Scanning Dynamic Competitive Landscapes: A Market-Based and Resource-Based Framework. Strategic Management Journal, 24, 1027-1041.

Rehman, W. U., Rehman, C. A., Rehman, H. U., Zahid, A. (2011). Intellectual Capital Performance and Its Impact on Corporate Performance: An Empirical Evidence from Modaraba Sector of Pakistan. Australian Journal of Business and Management Research, 1(5), 8-16.

Schaper, S., Nielsen, C. and Roslender, R. (2017). Moving From Irrelevant Intellectual Capital (IC) Reporting to Value-Relevant IC Disclosures: Key Learning Points From The Danish Experience. Journal of Intellectual Capital, 18(1), 82-101.

Shehzad, Umer, ZeeshanFareed, BushraZulfiqar, FarrukhShahzad and Hafiz ShahidLatif. (2014). The Impact of Intellectual Capital on the Performance of Universities. European Journal of Contemporary Education, 10(4), 273-280.

Soetrisno, AgustinusdanLina. (2014). The Influence of Intellectual Capital Components Towards The Company Performance. JurnalManajemen, 14(1), 125-140. 
Ulum, I. (2009). Intellectual Capital: Konsep dan Kajian Empiris. Yogyakarta: Graha IImu.

\section{APPENDIX}

TABLE 1

Model Summaryb

\begin{tabular}{|l|r|r|r|r|r|}
\hline Model & $\mathrm{R}$ & $\mathrm{R}$ Square & $\begin{array}{c}\text { Adjusted R } \\
\text { Square }\end{array}$ & $\begin{array}{c}\text { Std. Error of } \\
\text { the Estimate }\end{array}$ & $\begin{array}{c}\text { Durbin- } \\
\text { Watson }\end{array}$ \\
\hline 1 & $.231^{\mathrm{a}}$ & .053 & .033 & .07995 & 1.810 \\
\hline
\end{tabular}

a. Predictors: (Constant), IC

b. Dependent Variable: Financial Performance

TABLE 2

Coefficients $^{a}$

\begin{tabular}{|c|c|c|c|c|c|c|c|}
\hline \multirow[t]{2}{*}{ Model } & \multicolumn{2}{|c|}{$\begin{array}{c}\text { Unstandardized } \\
\text { Coefficients }\end{array}$} & $\begin{array}{c}\text { Standardized } \\
\text { Coefficients }\end{array}$ & \multirow[t]{2}{*}{$\mathrm{t}$} & \multirow[t]{2}{*}{ Sig. } & \multicolumn{2}{|c|}{ Collinearity Statistics } \\
\hline & B & Std. Error & Beta & & & Tolerance & VIF \\
\hline $\begin{array}{l}\text { (Constan } \\
1 \text { t) }\end{array}$ & .549 & .088 & & 6.208 & .000 & & \\
\hline IC & .096 & .060 & 231 & 1.608 & .115 & 1.000 & 1.000 \\
\hline
\end{tabular}

a. Dependent Variable: Financial Performance

TABLE 3

Model Summary

\begin{tabular}{|l|r|r|r|r|r|}
\hline Model & $\mathrm{R}$ & $\mathrm{R}$ Square & $\begin{array}{c}\text { Adjusted R } \\
\text { Square }\end{array}$ & $\begin{array}{c}\text { Std. Error of } \\
\text { the Estimate }\end{array}$ & $\begin{array}{c}\text { Durbin- } \\
\text { Watson }\end{array}$ \\
\hline 1 & $.392^{\mathrm{a}}$ & .154 & .116 & .07642 & 2.149 \\
\hline
\end{tabular}

a. Predictors: (Constant), ICD, IC

b. Dependent Variable: Financial Performance

TABLE 4

Coefficients $^{\mathrm{a}}$

\begin{tabular}{|c|c|c|c|c|c|c|c|}
\hline \multirow[t]{2}{*}{ Model } & \multicolumn{2}{|c|}{$\begin{array}{c}\text { Unstandardized } \\
\text { Coefficients }\end{array}$} & $\begin{array}{c}\text { Standardized } \\
\text { Coefficients }\end{array}$ & \multirow[t]{2}{*}{$\mathrm{t}$} & \multirow[t]{2}{*}{ Sig. } & \multicolumn{2}{|c|}{$\begin{array}{c}\text { Collinearity } \\
\text { Statistics }\end{array}$} \\
\hline & $B$ & Std. Error & Beta & & & $\begin{array}{c}\text { Toleranc } \\
\mathrm{e}\end{array}$ & VIF \\
\hline $\begin{array}{l}\text { (Constan } \\
\text { t) }\end{array}$ & .729 & . 115 & & 6.343 & .000 & & \\
\hline $\begin{array}{ll}1 & \text { IC }\end{array}$ & .081 & .057 & .195 & 1.412 & .165 & .987 & 1.013 \\
\hline ICD & -.338 & .146 & -.319 & -2.314 & .025 & .987 & 1.013 \\
\hline
\end{tabular}

a. Dependent Variable: Financial Performance 
TABLE 5

Model Summary

\begin{tabular}{|l|r|r|r|r|r|}
\hline Model & $\mathrm{R}$ & $\mathrm{R}$ Square & $\begin{array}{c}\text { Adjusted R } \\
\text { Square }\end{array}$ & $\begin{array}{c}\text { Std. Error of } \\
\text { the Estimate }\end{array}$ & $\begin{array}{c}\text { Durbin- } \\
\text { Watson }\end{array}$ \\
\hline 1 & $.404^{\mathrm{a}}$ & .163 & .126 & .07600 & 2.168 \\
\hline
\end{tabular}

a. Predictors: (Constant), Interaction, IC

b. Dependent Variable: Financial Performance

TABLE 6

Coefficients $^{\mathrm{a}}$

\begin{tabular}{|c|c|c|c|c|c|c|c|}
\hline \multirow[t]{2}{*}{ Model } & \multicolumn{2}{|c|}{$\begin{array}{c}\text { Unstandardized } \\
\text { Coefficients }\end{array}$} & $\begin{array}{c}\text { Standardized } \\
\text { Coefficients }\end{array}$ & \multirow[t]{2}{*}{$\bar{t}$} & \multirow[t]{2}{*}{ Sig. } & \multicolumn{2}{|c|}{$\begin{array}{c}\text { Collinearity } \\
\text { Statistics }\end{array}$} \\
\hline & $B$ & Std. Error & Beta & & & $\begin{array}{c}\text { Toleranc } \\
\mathrm{e}\end{array}$ & VIF \\
\hline (Constant) & .570 & .084 & & 6.745 & .000 & & \\
\hline 1 IC & .196 & .070 & .472 & 2.799 & .008 & .654 & 1.530 \\
\hline Interaction & -.245 & .101 & -.410 & -2.432 & .019 & .654 & 1.530 \\
\hline
\end{tabular}

a. Dependent Variable: Financial Performance 